\title{
Mechanical damage on Bird-of-Paradise (Strelitzia reginae) postharvest ${ }^{(1)}$
}

\author{
GLÁUCIA M. DIAS(2); SARA J. QUEIROZ(2), JULIANA SANCHES(2); \\ ANTONIO FERNANDO C. TOMBOLATO(2)
}

\begin{abstract}
The marketing of strelitzia (Strelitzia reginae) has been increasing due to its beauty, exotic colors and high post-harvest longevity. It has potential to increase also in international exports, however this has been limited by the scarcity of information on the flower post-harvest management and packaging. Therefore, this study aimed to further the technology of strelitzia postharvest to maintain high quality of the product and to select a packaging system suitable for export, ensuring high quality to the final consumer. The damages of the stem and the petal color on the buds of Strelitzia reginae were evaluated and it was observed that the stalks harvested with closed buds had extended longevity, while the flower stalks harvested with the first opened button had the highest flower opening rate. As for mechanical damage, the sleeve net protection most affected the visual appearance of the flowers. The cardboard box packaging showed the lowest percentage of damage in the stems.
\end{abstract}

Keywords: cut flower, packaging, longevity

\section{RESUMO}

Danos mecânicos na pós-colheita de Ave do paraiso (Strelitżia reginae)

\begin{abstract}
A comercialização de strelitzia (Strelitzia reginae) está aumentando devido a sua beleza, cores exóticas e alta longevidade na pós-colheita. Esta tem potencial para aumentar também nas exportações internacionais, no entanto o aumento tem sido limitado pela escassez de informação sobre pós-colheita da flor e embalagem. Portanto, este estudo teve como objetivo desenvolver tecnologia pós-colheita de strelitzia para manter a alta qualidade do produto e selecionar um sistema de embalagem adequada para a exportação, garantindo alta qualidade para o consumidor final. Os danos do caule e a cor pétala de Strelitzia reginae foram avaliados, e observou-se que as hastes colhidas com botões fechados tinha longevidade estendida, enquanto as hastes florais colhidas com o primeiro botão aberto apresentou maior taxa de abertura da floral. Quanto a danos mecânicos, a rede de proteção foi o que mais afetou o aspecto visual das flores. Na caixa de papelão observou se o menor percentual de danos nas hastes.
\end{abstract}

Palavras-chave: flor de corte, embalagem, longevidade

\section{INTRODUCTION}

The strelitzia (Strelitzia reginae Aiton), also commonly called bird of paradise, is original from South Africa. It is a very popular and highly appreciated cut flower in the world floriculture market due to its exotic appearance and high durability (Barreto, 2008; Terao; Barroso and Carvalho, 2005).

Brazil has great chances to become a significant producer and exporter of flowers and ornamental plants in the world, but there are challenges to be overcome. Aspects such as: application of advanced technologies in production systems, use of appropriate genetic material, training and qualification of labor, professional management, market, logistics and distribution, structures of market organization and incentives to technologies and post-harvest packaging need to be improved (Salome, 2007).

Maintaining postharvest quality of cut flowers is extremely important to compensate all the effort spent during the production. According to Lima and Moraes Silva (2006) the post-harvest losses can reach $50 \%$ of the total harvested. Often the reduction of these losses is more economically viable than the increase in production. For this reason, growers and brokers need to understand the biological and environmental factors involved in the deterioration and employ appropriate post-harvest techniques, delaying senescence and maintaining the best quality of the products (Dias-Tagliacozzo and Mosca, 2007).

Mechanical damage in plants can lead to physical, chemical, physiological and biochemical changes that can modify color and texture. They are caused by abrasions, cuts, breaks or denting, besides serving as a gateway to pathogenic microorganisms, resulting in death of the outer cells and giving an unpleasant appearance to the product (Castro et al., 2001; Chitarra and Chitarra, 2005).

The use of packaging suitable for shipping and marketing helps to reduce mechanical damages, maintaining product quality and reducing losses in the post-harvest (Chitarra and Chitarra, 1990). Also, like fruits and vegetables, flowers deteriorate quickly because of catabolic physiological processes that occur more intensely after harvest, so once

\footnotetext{
(1) Recebido em 30 de novembro de 2012 e aceito para publicação em 20 de setembro de 2013 .

(2) Instituto Agronômico, SP, BR- P.O. Box 28, CEP 13012-97

Brazil - corresponding autor email:glaucia@iac.sp.gov.br
} 
packed, the flowers should be immediately stored (LIMA et al., 2006).

This study aimed to evaluate how longevity and color of "arrow" petal of flower stalks of Strelitzia reginae are affected by different types of mechanical damage and to identify the most suitable packaging for transport (correlated to protection against mechanical damage).

\section{MATERIAL AND METHODS}

The study was carried out in the Laboratory of Postharvest Technology Center Engineering and Automation of the Agronomic Institute, in Jundiaí/SP. The flower stalks of Strelitzia reginae were produced by the grower Aguinaldo Mitsuo Kikuchi in his farm in Itupeva-SP.

For this research, two phases were established, as follow:

Phase 1. Material characterization and identification of mechanical damage.

The flower stalks were harvest one day before the experiment started at two stages of development - one with the spathe still closed (treatment Button) and another one with the first button opened (treatment FRO, with the first rapier open).

For both stages, 140 stems were selected $-10 \mathrm{~cm}$ of the stems base were cut and secondary buds were removed. After these procedures, the flower stems were transferred to glass vases containing tap water. Samples of 30 stems of both treatments were weighed throughout the experiment. The 30 samples of both treatments were identified to ensure that the fresh weight was collected from the same samples and weighted to evaluate the percentage of weight loss.

The vessel water was changed and the evaluation of the mechanical injuries was made every two days, while the fresh weight of stems was measured every four days. The color of the "arrow" petal was assessed immediately after opening the floret.

Stems were numbered and evaluated one by one, and each stem represented one sample. The evaluation was made according to the presence of mechanical injuries, potassium deficiency, color of the "arrow" (blue petal), spathe and stem length, number of opened florets and longevity of the flower stems.

Phase 2. Different packages test and evaluation of the presence of mechanical damage in flower stems and cardboard box ) and the control (from harvest straight to the laboratory)

Treatment evaluation for the presence of mechanical injuries, color of the "arrow" petal, number of open florets and longevity were made every two days.

The experimental design was completely made at random. Besides the control, the other treatments were: simple packet, packet with sleeve net protection and cardboard box (figure1). Each treatment consisted of three replications, for the bouquet treatment each replicate contained 36 stems, while for the cardboard box, each replicate contained 40 flower stems.

\section{RESULTS AND DISCUSSIONS}

The average lifespan was 12.5 days for the stems harvested with the first open button (FRO) and 14.2 days for the Button stage. It was observed that the point of harvest influenced the longevity of flowers. Stems harvested with the button fully closed had 1.13 times as much longevity than those collected with the first rapier open. However, the flower stalks harvested and transported with closed buds had lower flower opening. Ninety four percent $(94.2 \%)$ of the flower stalks in button treatment opened the 1st foil; $40.1 \%$ opened the 2 nd foil, $5.11 \%$ opened the $3 \mathrm{rd}$ and $0 \%$ opened the 4 th foil. Those that were harvested with the first rapier already open (FRO) had 99.3\%, 81\%, 21.2\% and $1.46 \%$ of flowers opened on the 1 st, 2 nd, 3 rd and 4 th foil, respectively.

Flower stalks harvested with fully closed buds (treatment Button) showed the greatest longevity, but flower stalks harvested with the first rapier already open (FRO) had the highest flower opening. Therefore, if the sale of the flowers is for the domestic market, the ideal harvest time would be when the first foil starts to open. On the other hand, when the destination is overseas and packaging in boxes is recommended, it is recommended stage to harvest when the buttons are still closed.

The color of the petal "arrow" in most florets (newly opened flowers) was dark blue. The phase that had a higher percentage of button petal "arrow" in the first dark foil, but in the second and third the percentage of petal "arrow" dark was lower (Table 1).

The characterization of the material identified some mechanical damages on the petals of flowers (abrasion, cut surface, kneading and tearing) and spathe (cutting and kneading) (Figure 2)

Mechanical damage in button stems were minor compared to those harvested with the first opening button (FRO) (Figure 3), this result is that the flowers are protected by sheaths, while in the other the flower is very exposed to injuries, especially the first foil.

The percentage of weight loss during the process of senescence was $0.16 \%$ for FR0 and $0.12 \%$ for Button treatment. These weight losses were relatively low when compared to other species.

The fresh weight of petals and reproductive structures was not measured individually in this study because the flower stalks had to be kept intact for evaluation of mechanical damage and packaging, the main objectives of this study. . However, it was possible to observe wilting of the sepals, petals and reproductive structure during the experiment

The Phase 2 compared the influence of the packaging on the longevity of strelitzia stalks. On average, flowers from the simple packet lasted 14.62 days from the packet with sleeve net protection lasted 12.9 days and from the cardboard box lasted 13.64 days and the control treatment lasted 14 days. As the data shows, it was observed that the longevity of the flowers was higher with the flower stalks packed into the cardboard box compared to the packet treatments with and or without sleeve net. 
The stems packed in simple packets showed that the tip of the spathe were more susceptible to crushing. The cardoboard box treatment and the packet with sleeve net protection exhibited the most damages in the flowers ( $>$ $20 \%$ flowers at $1^{\text {st }}$ floret) and the packet without sleeve net protection and control treatment resulted in the highest torn and crushed flower rates ( $>30 \%$ of damages in flowers at the florets) (Figure 4 and Table 2). In general, the packaging using cardboard box has presented the least mechanical damage. Castro and Jorge Cortez (2001), despite not finding significant differences in the different types of packages tested in tomato during shipping and handling, observed that the cardboard box presents lower percentage of injured fruits.

The presence of mechanical damage in floral stems does not necessarily compromise the appearance of the flowers, as it is often very slight and the flower still remains attractive. Visually, the petals were torn and severed the depreciated more than the flowers, leaving them with little pleasant aspect.

Despite the fact that the cardboard box treatment presented the lowest percentage of mechanical injury, this treatment had the lowest opening of floral petals and the highest percentage of white arrows in the 2 nd and $3 \mathrm{rd}$ flower (Table 3). Treatments that least affected the color of the arrows were the control treatment and the bouquet without sleeve net protection (Figure 5).

\section{CONCLUSIONS}

The tear was the mechanical injury that most interfered in the visual appearance of the flowers. To decrease the percentage of mechanical injuries in strelitzia stalks packaging it is recommended to use the cardboard box during the transport.

\section{REFERENCES}

Barreto, R. Estrelítzia - Strelitzia reginae. 2008. Available at: <http://www.jardineiro.net/br/banco/strelitzia_reginae. php> . Accessed: 29 mai. 2008.

Castro, C.E.F. Tratamentos químicos pós-colheita e critérios de avaliação da qualidade de cravos (Dianthus caryophyllus L.) cv. Scania Red Sim. 1984. 139fl. Tese (Mestrado). Escola Superior de Agricultura "Luiz de Queiroz”, Universidade de São Paulo, Piracicaba, SP. 1984.

Castro, L.R.; Cortez, L.A.B.; Jorge, J.T. Influência da embalagem no desenvolvimento de injúrias mecânicas em tomates. Ciência Tecnologia Alimentos, Campinas, 21(1): p.26-33, jan.-abr. 2001.

Chitarra, M.I.F.; Chitarra, A.B. Pós-colheita de frutas e hortaliças: fisiologia e manuseio. 2. ed. Rev. e ampl. Lavras: UFLA, 2005. 785p.

Chitarra, M.I.F.; Chitarra, A.B. Pós-colheita de frutos e hortaliças: fisiologia e manuseio. Lavras: ESALQ/FAEPE, 1990. 320p.

Dias-Tagliacozzo, G. M. Tecnologia Pós-colheita para Plantas Ornamentais. In: Ambiente protegido: olericultura, citricultura e floricultura. Ed. Viçosa: Suprema Gráfica e Editora Ltda., v.1, p. 151-170. 2006.

Dias-Tagliacozzo, G. M. D., Mosca, J. L. Pós-colheita de flores e Folhagem. Revista Brasileira de Horticultura Ornamental, v.13, p.209 219. 2007.

Dias-Tagliacozzo, G.; Zullo, M.A.; Castro, C.E.F. 2003. Caracterização física e conservação pós-colheita de alpínia. Revista Brasileira de Horticultura Ornamental, Campinas, v.9, n.1, p. 17-23.

Finger, F.L.; Moraes, P.J.; Cecon, P.R.; Barbosa, J.G.; Alvares, V.S. 1999. Efeito da refrigeração e do condicionamento em sacarose sobre a longevidade de inflorescências de Strelitzia reginae Ait. Revista Brasileira de Horticultura Ornamental, Campinas, v. 5, n. 2, p. 151-156.

Halevy, A.H.; Kofranek, A.M.; Besemer, S.T. 1978. Postharvest handling methods for Bird-of-paradise flowers (Strelitzia reginae Ait.). J. Amer. Soc. Hort. Sci. 103(2):165-169.

Lima, J.; Moraes, W.; Silva, C. Tecnologia pós-colheita de Flores de Corte. Vale do Ribeira-SP, UNESP. 2006. Available at: <http://www.biologico.sp.gov.br/rifib/ XIVRifib/lima.PDF>. Acesso em: 16 ago. 2007.

Mattiuz, C.F.M. Fisiologia pós-colheita de inflorescências de Alpinia purpurata (Vieill) K. Schum. Jaboticabal, Tese (Doutorado), 2003.Universidade Estadual Paulista, Faculdade de Ciências Agrárias e Veterinárias. 2003.

Moraes, P.J.; Cecon, P.R.; Finger, F.L., Barbosa, J.G.; Alvares, V.S. 1999. Efeito da refrigeração e do condicionamento em sacarose sobre a longevidade de inflorescências de Strelitzia reginae Ait. Revista Brasileira de Horticultura Ornamental, Campinas, v.5, n.2. p. 151156.

Salomé, J.R. Mercado Brasileiro de Flores e Plantas Ornamentais. 2007. Available in: <http://www. aptaregional.sp.gov.br/artigo.php?id_artigo $=511>$. Acesso em: 28 nov. 2007.

Sangalli, A; Scalon, S.P.Q.; Carvalho, J.C.L. Perda de massa de flores de capuchinha após armazenamento. Horticultura Brasileira, v. 25, n.3, 471-474, 2007.

Terao, D.; Carvalho, A.P.P.; Barroso, T.C.S.V. 2005. Flores tropicais: tropical flowers. Brasilia: Embrapa Informação Tecnológica, $225 \mathrm{p}$. 
Table 1. "Arrow" petal color in strelitzia floral stalks from button and FRO, just after the floret opening

\begin{tabular}{|c|c|c|c|c|c|c|c|c|}
\hline \multirow{3}{*}{ Treatment } & \multicolumn{4}{|c|}{$\%$ light arrow petal color } & \multicolumn{4}{|c|}{$\%$ dark Arrow petal color } \\
\hline & \multicolumn{4}{|c|}{ Floret } & \multicolumn{4}{|c|}{ Floret } \\
\hline & $1^{\mathrm{a}}$ & $2^{\mathrm{a}}$ & $3^{\mathrm{a}}$ & $4^{a}$ & $1^{a}$ & $2^{\mathrm{a}}$ & $3^{\mathrm{a}}$ & $4^{a}$ \\
\hline Button & 12,1 & 48,2 & 42,9 & - & 87,9 & 51,8 & 57,1 & - \\
\hline FRO & 30,9 & 25,9 & 27,6 & 0 & 69,1 & 74,1 & 72,4 & 100 \\
\hline
\end{tabular}

Table 2. Percentage of opened florets on stalks of strelitzia under 4 packaging treatments: simple packet, packet with sleeve net protection and cardboard box

\begin{tabular}{|c|c|c|c|c|}
\hline \multirow{2}{*}{ Treatments } & \multicolumn{4}{|c|}{ Opened Florets (\%) } \\
\hline Cardboard box & 1 & 2 & 3 & 4 \\
\hline $\begin{array}{c}\text { packet with sleeve } \\
\text { net }\end{array}$ & 93,4 & 47,07 & 2,635 & 0 \\
\hline Simple packet & 92,59 & 50,05 & 8,414 & 0,98 \\
\hline Control & 87,11 & 86,21 & 19,4 & 0,926 \\
\hline
\end{tabular}

Table 3. Coloring of "arrow" petal just after opening the button, in different treatments of flower stalks of strelitzia

\begin{tabular}{|c|c|c|c|c|c|c|c|c|c|c|c|c|}
\hline \multirow{3}{*}{ Treatment } & \multicolumn{4}{|c|}{ White (\%) } & \multicolumn{4}{|c|}{ Light blur (\%) } & \multicolumn{4}{|c|}{ Dark blue (\%) } \\
\hline & \multicolumn{4}{|c|}{ Floret } & \multicolumn{4}{|c|}{ Floret } & \multicolumn{4}{|c|}{ Floret } \\
\hline & $1^{\circ}$ & $2^{\circ}$ & $3^{\circ}$ & $4^{\circ}$ & $1^{o}$ & $2^{\circ}$ & $3^{\circ}$ & $4^{o}$ & $1^{\circ}$ & $2^{\circ}$ & $3^{\circ}$ & $4^{\circ}$ \\
\hline $\begin{array}{c}\text { Cardboard } \\
\text { box }\end{array}$ & 0 & 12,9 & 32,4 & - & 13,4 & 59,4 & 35,1 & - & 86,6 & 27,7 & 32,4 & - \\
\hline $\begin{array}{l}\text { packet with } \\
\text { sleeve net }\end{array}$ & 0 & 1,2 & 0 & 0 & 20 & 48,2 & 100 & 0 & 80 & 50,6 & 0 & 100 \\
\hline $\begin{array}{l}\text { Simple } \\
\text { packet }\end{array}$ & 1,1 & 4,4 & 4,6 & 0 & 21,1 & 35,9 & 47,5 & 0 & 77,9 & 59,8 & 47,8 & 100 \\
\hline Control & 0 & 2,3 & 5,6 & 0 & 18,5 & 31,1 & 49,9 & 100 & 81,5 & 66,7 & 44,5 & 0 \\
\hline
\end{tabular}



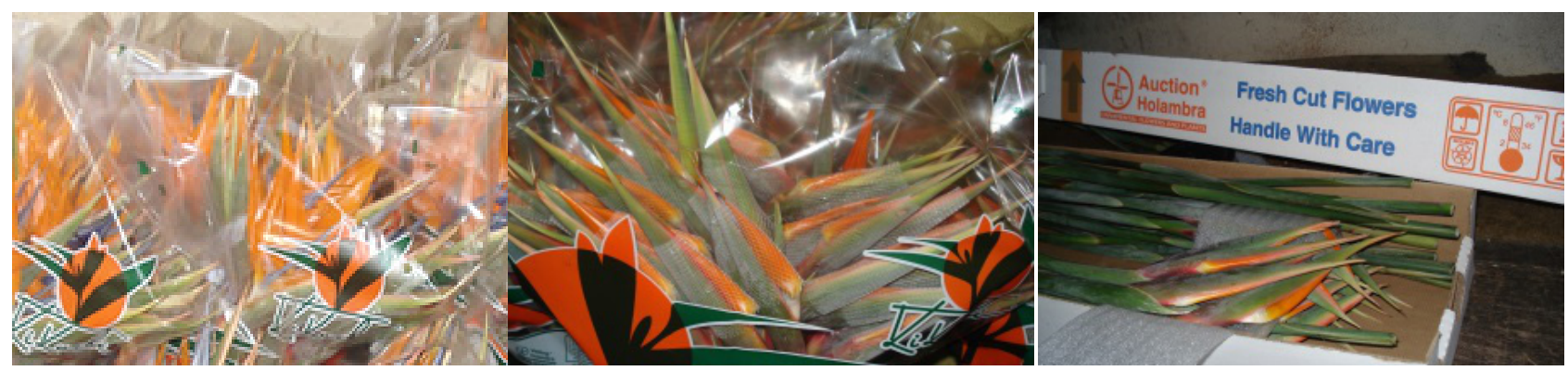

Figure 1. simple packet, packet with sleeve net and cardboard box.

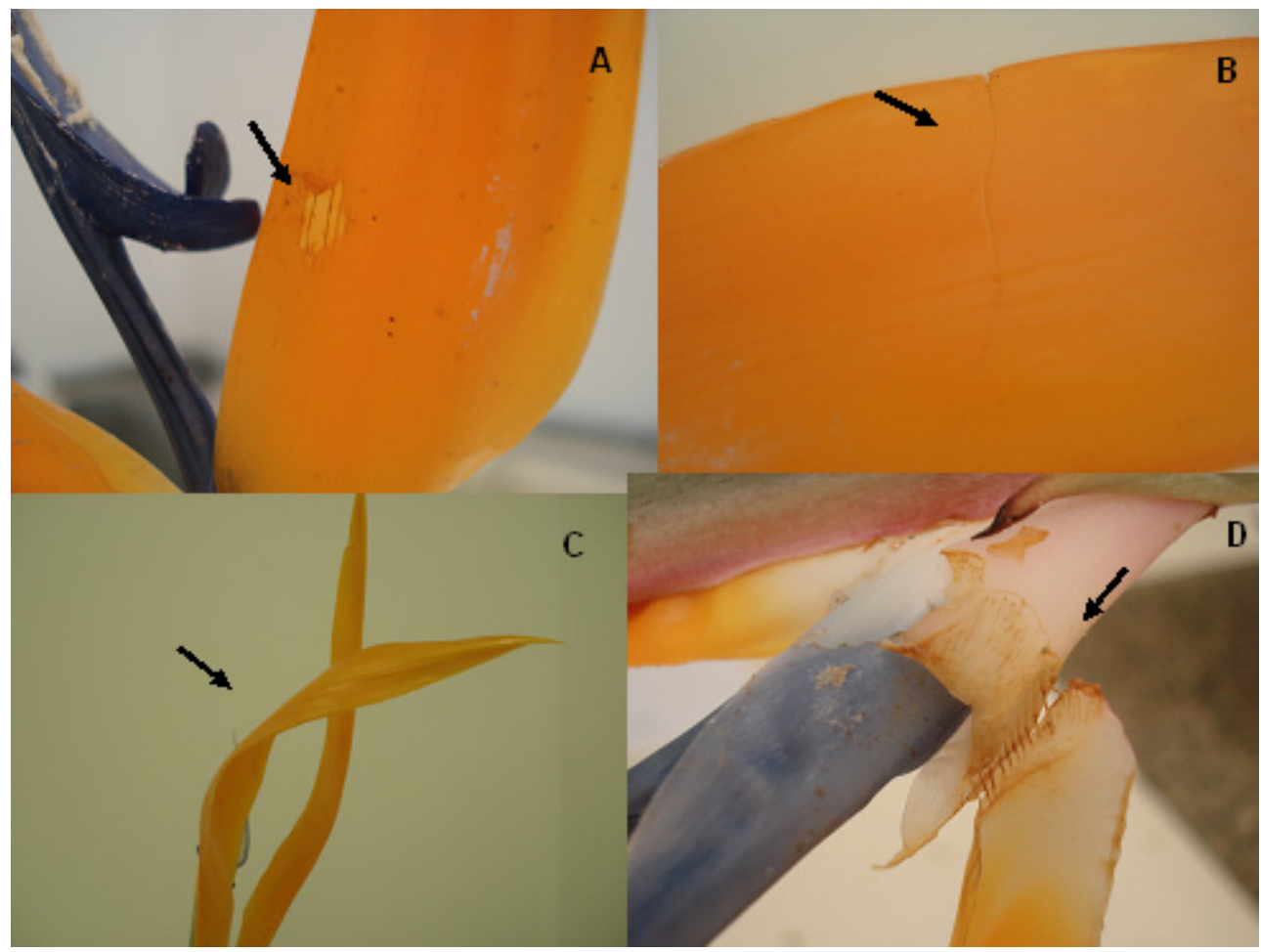

Figure 2. Flower stalk of Strelitzia reginae with major mechanical injuries found on the petals. Namely: abrasion (A), cutting surface, (B), kneading (C) and tearing (D).

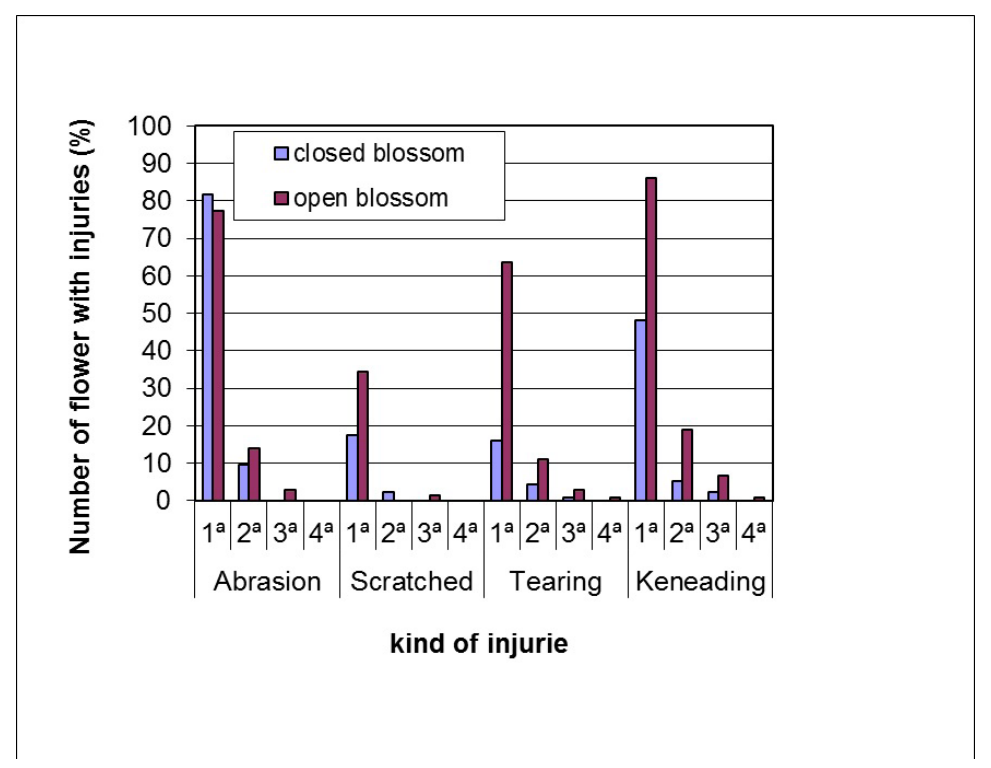

Figure 3. Percentage of mechanical injuries in florets on stalks of strelitzia from bottom and FRO 


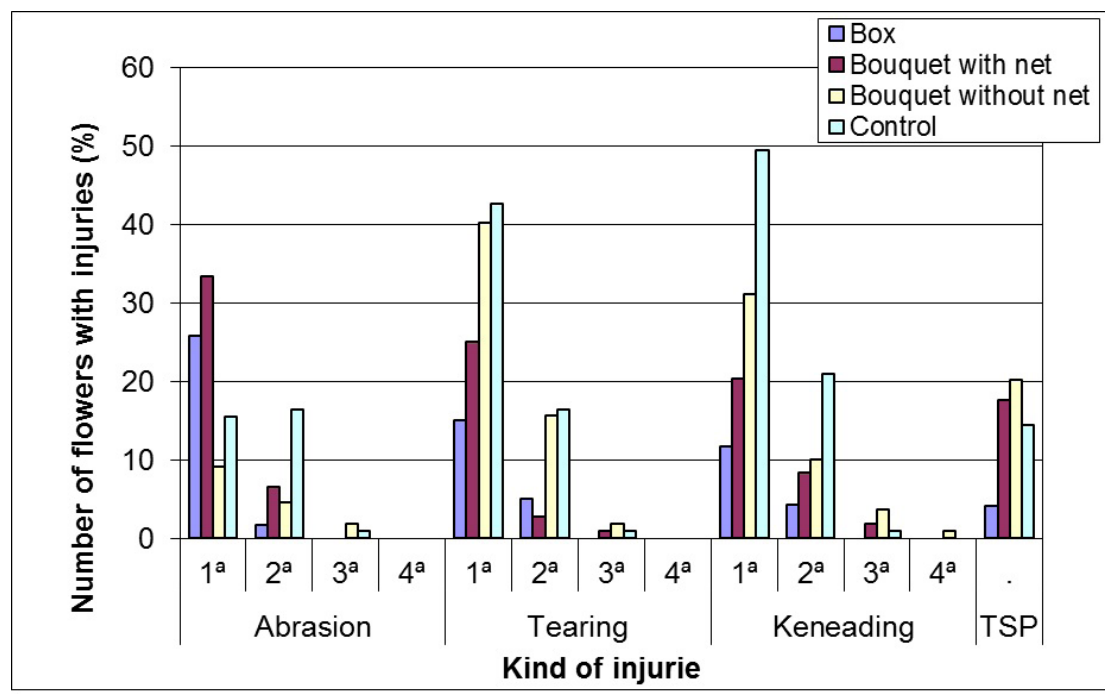

Figure 4. Mechanical injuries observed in flower stalks of strelitzia subjected to different packaging (box, bouquet with net, bouquet without net and control).

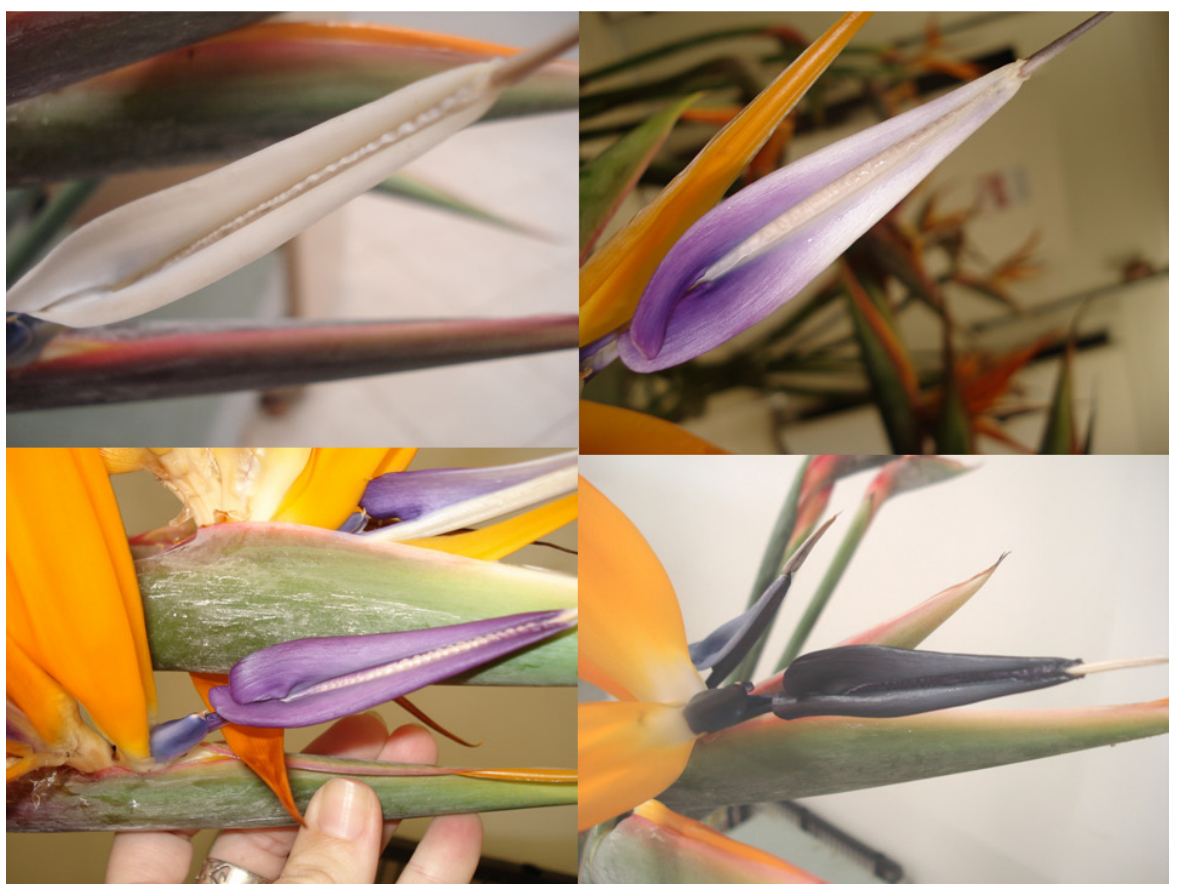

Figure 5. Different colors of "arrow" petal, classified as white, light blue, medium blue and dark blue 